\title{
ЗАСІБ АВТОМАТИЗАЦИИ КОНТРОЛЮ РОБОЧОГО СЕРЕДОВИЩА ГАЗОТУРБОНАГНІТАЧІВ
}

\author{
Карпілов О.Ю.
}

Національний університет "Одеська морська академія", м. Одеса, Україна

E-mail: kau.onma@gmail.com

Copyright (C) 2021 by author and the journal "Automation of technological and business - processes". This work is licensed under the Creative Commons Attribution International License (CC BY). http://creativecommons.org/licanses/by/4.0

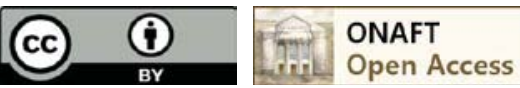

DOI:

Аннотація. У великих морських та річкових транспортних кластерах частка забруднень повітряного середовища, що належить судновим енергетичним установкам, перебільшує 7 \% від загальної кількості викидів шкідливих речовин. Екологічний збиток, викликуваний роботою теплових двигунів внутрішнього згоряння, складається як з забруднення середовища газами, щзо відробили, так й "температурному забрудненні" - викидах у довкілля великої кількості низькотемпературної теплоти. Надлишкова теплота ініціює різні кліматичні аномалї глобального характеру. Істотний вплив на катастрофічні процеси виявляє "парниковий ефект", щзо приводить до зміни характеру променистого теплообміну між земною поверхнею й шарами атмосфери внаслідок збільшення вмісту в ній діоксиду вуглецюю. Рамкова конвенція ООН про зміну клімату (UN FCCC) $i$ Кіотський протокол 1997 р. визначили державні зобов'язання для краӥн-учасниць відносно зниження викидів СО . В 1997 р. на Міжнародній конференції сторін Міжнародної конвенції по запобіганню забруднення із судів (МАРПОЛ) була прийнята Резолюиія 8 по "викидах вуглекислого газу із суден", у якій Міжнародної морської організації (IМО) у співробітництві із Секретаріатом Рамкової конвенції Організації Об'єднаних Націй про зміну клімату було запропоновано запровадити комплекс заходів щзодо вивчення впливу викидів парникових газів із суден з метою встановлення кількості й відносного проиентного вмісту викидів вуглекислого газу з суден. На підставі аналізу результатів досліджень, виконаних у 2007 p., визначено, щуо частка викидів парникових газів у міжнародному судноплавстві вже склала приблизно 2,7 \% світових викидів $C_{2}$. Для подальшого зниження впливу суден та кораблів на якість навколишнього середовища необхідна реорганізація енерговикористання в суднових енергетичних установках. Поставлена задача вирішується тим, щьо волоконно-оптичний датчик вуглекислого газу, щчо складається з основи, світловода, мембрани, джерела випромінювання та фотоприймача та який відрізняється тим, щзо світловод є револьверного типу, зафіксований у основі, з одного боку сполучається з розгалужувачем, джерелом випромінювання та фотоприймачем, зв'язаних 3 блоком живлення та реєстрації. 3 другого боку світловод на ториі має віддзеркалюючий шар та сполучений 3 мембраною, яка є газопроникною. Внутрішні отвори світловода вкриті шаром оксиду індію-олова, а зовні світловод вкритий термокомпенсачійною оболонкою та захисним чохлом.

Abstract. In large marine and river transport clusters, the share of air pollution belonging to ship power plants exceeds 7\% of the total emissions of harmful substances. The environmental damage caused by the operation of internal combustion engines consists of both pollution of the environment with exhaust gases and "temperature pollution" - emissions of large amounts of low-temperature heat. Excess heat initiates various global climatic anomalies. The "greenhouse effect" has a significant effect on catastrophic processes, which leads to a change in the nature of radiant heat exchange between the earth's surface and the atmosphere due to an increase in the content of carbon dioxide. The United Nations Framework Convention on Climate Change (UN FCCC) and the 1997 Kyoto Protocol set out national commitments for member states to reduce C2 emissions. In 1997, the International Conference of the Parties to the International Convention for the Prevention of Pollution from Ships (MARPOL) adopted Resolution 8 on "carbon emissions from ships", in which the International Maritime Organization (IMO) in cooperation with the Secretariat of the Framework Convention of the United Nations On climate change, it was proposed to introduce a set of measures to study the impact of greenhouse gas emissions from ships in order to determine the amount and relative percentage of carbon dioxide emissions from ships. Based on the analysis of the results of research conducted in 2007, it was determined that the share of greenhouse gas emissions in international shipping has already amounted to approximately $2.7 \%$ of global $\mathrm{CO}_{2}$ emissions. To further reduce the impact of ships and vessels on the quality of the environment, it is necessary to reorganize energy use in ship power plants. The problem is solved by the fact that the fiber-optic carbon dioxide sensor, consisting of a base, fiber, membrane, radiation source and photodetector and characterized in that the fiber is a revolving type, fixed in the base, on the one hand communicates with the splitter, radiation source and a photodetector connected to the power supply and registration. On the other hand, the fiber at the end has a 
reflective layer and is connected to a membrane that is gas permeable. The inner openings of the fiber are covered with a layer of indium-tin oxide, and the outer fiber is covered with a thermal compensation shell and a protective cover.

Ключові слова: вуглекислий газ, волоконно-оптичний, датчик.

Key words: carbon dioxide, fiber-optic, sensor.

\section{Вступ}

Згоряння рідких вуглеводневих енергоносіїв на суднах та кораблях супроводжується викидом в атмосферу токсичних з'єднань, оксидів вуглецю й твердих часток, що є небезпечним джерелом забруднення навколишнього середовища. За аналітичними даними економічний збиток від шкідливого впливу на екологічним стан довкілля досягає 10 \% від вартості внутрішнього валового продукту.

У великих морських та річкових транспортних кластерах частка забруднень повітряного середовища, що належить судновим енергетичним установкам, перебільшує 7 \% від загальної кількості викидів шкідливих речовин. Екологічний збиток, викликуваний роботою теплових двигунів внутрішнього згоряння, складається як з забруднення середовища газами, що відробили, так й "температурному забрудненні" - викидах у довкілля великої кількості низькотемпературної теплоти. Надлишкова теплота ініціює різні кліматичні аномалії глобального характеру. Істотний вплив на катастрофічні процеси виявляє "парниковий ефект", що приводить до зміни характеру променистого теплообміну між земною поверхнею й шарами атмосфери внаслідок збільшення вмісту в ній діоксиду вуглецю.

Рамкова конвенція ООН про зміну клімату (UN FCCC) і Кіотський протокол 1997 р. визначили державні зобов'язання для країн-учасниць відносно зниження викидів $\mathrm{C}_{2}$. В 1997 р. на Міжнародній конференції сторін Міжнародної конвенції по запобіганню забруднення із судів (МАРПОЛ) була прийнята Резолюція 8 по "викидах вуглекислого газу із суден", у якій Міжнародної морської організації (IMO) у співробітництві із Секретаріатом Рамкової конвенції Організації Об'єднаних Націй про зміну клімату було запропоновано запровадити комплекс заходів щодо вивчення впливу викидів парникових газів із суден 3 метою встановлення кількості й відносного процентного вмісту викидів вуглекислого газу з суден.

На підставі аналізу результатів досліджень, виконаних у 2007 р., визначено, що частка викидів парникових газів у міжнародному судноплавстві вже склала приблизно 2,7 \% світових викидів $\mathrm{CO}_{2}$. Для подальшого зниження впливу суден та кораблів на якість навколишнього середовища необхідна реорганізація енерговикористання в суднових енергетичних установках.

При проведенні такої реорганізації необхідно забезпечити наявність на суднах вимірювальних пристроїв контролю вмісту вуглекислого газу у відпрацьованих газах, що забезпечать високу вірогідність результатів вимірювання [1 - 3].

\section{Аналіз літературних джерел та постановка задачі}

У той же час, аналіз існуючих пристроїв контролю вмісту вуглекислого газу показав таке. Можливості більшості використовуваних датчиків не дозволяють реалізувати ефективний моніторинг робочого середовища газотурбонагнітачів двигунів внутрішнього згоряння. Спільними проблемами для всіх типів засобів контролю $є$ проблеми чутливості, швидкодії і стабільності чутливого елемента, які визначають достовірність результатів вимірювань.

Для пошуку шляхів удосконалення засобів контролю вмісту вуглекислого газу були розглянуті конструкції найбільш поширених засобів цього класу.

Відомий датчик, що основу, світловод, нейтральний світлофільтр, дихроїчне дзеркало, мембрану, гідрофільне середовище полімерної матриці з флуоресціюючою речовиною, джерело випромінювання та фотоприймач [4].

Недоліки пристрою, які обумовлені застосуванням світлофільтру, дихроїчного дзеркала, гідрофільного середовища полімерної матриці з флуоресціюючою речовиною:

- необхідність дотримання чистоти поверхонь додаткових оптичних елементів для запобігання похибок вимірювання;

- необхідність постійного підтримання властивостей оптичного каналу, та особливо гідрофільного середовища полімерної матриці з флуоресціюючою речовиною, в умовах впливу кліматичних та експлуатаційних факторів;

- надвеликий час формування сталого сигналу;

- складність заміни пошкоджених світловодів.

Найбільш близьким за технічною сутністю та результатом, що досягається, до винаходу, що пропонується, є датчик, що містить основу, світловод, перший реагент з карбіду кремнію, другий реагент органічного походження, джерело випромінювання та фотоприймач [5].

Недоліки пристрою, які обумовлені застосуванням двох типів реагентів:

- вузький робочий температурний діапазон;

- неможливість урахування впливу кліматичних та експлуатаційних факторів на результати вимірювання через застосування реагенту органічного походження;

- необхідність застосування світловоду зі штучного алмазу, як матеріалу показник заломлення якого перевищує показник заломлення карбіду кремнію, для реалізації умов повного внутрішнього відбивання світла у світловоді;

- неможливість урахування впливу складових газового середовища, які мають близькі характеристики. 


\section{Мета та задачі дослідження}

Таким чином, актуальною є задача створення датчику вуглекислого газу, у якому відсутня необхідність постійної підтримки чистоти оптичних поверхонь та властивостей оптичного каналу, застосовані менш коштовні матеріали та одночасно збережені надійність, чутливість та простота схемотехнічних рішень датчиків відомих типів.

\section{Результати дослідження}

Поставлена задача вирішується тим, що волоконно-оптичний датчик вуглекислого газу, що складається 3 основи, світловода, мембрани, джерела випромінювання та фотоприймача та який відрізняється тим, що світловод $є$ револьверного типу, зафіксований у основі, з одного боку сполучається з розгалужувачем, джерелом випромінювання та фотоприймачем, зв'язаних 3 блоком живлення та реєстрації. 3 другого боку світловод на торці має віддзеркалюючий шар та сполучений з мембраною, яка є газопроникною. Внутрішні отвори світловода вкриті шаром оксиду індію-олова, а зовні світловод вкритий термокомпенсаційною оболонкою та захисним чохлом.

Суть винаходу пояснюється кресленням (рис. 1), де зображено волоконно-оптичний датчик вуглекислого газу, який складається 3 основи 1, вкритої термокомпенсаційною оболонкою 11, волоконно-оптичного світловоду револьверного типу 3 , зафіксованого у основі.

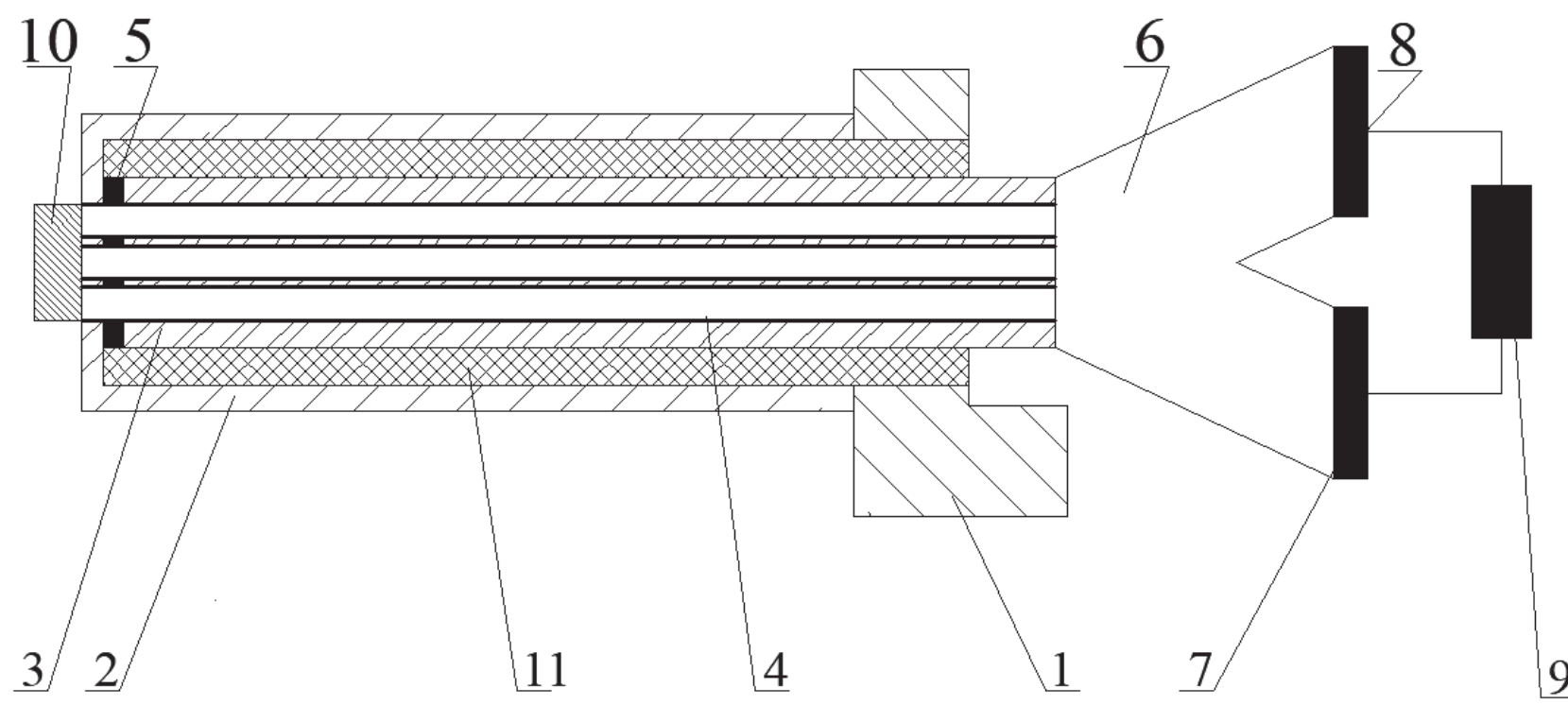

Рис. 1. - Волоконно-оптичний датчик вуглекислого газу: 1 - основа; 2 - захисний чохол; 3 - світловод; 4 - шар оксиду індію-олова; 5 - віддзеркалюючий шар; 6 - розгалужувач; 7 - джерело випромінювання; 8 фотоприймач; 9 - блок живлення та ресстрації; 10 - газопроникна мембрана; 11 - термокомпенсаційна оболонка

Внутрішні отвори світловоду вкриті шаром індію-олова 4. На одному з торців світловода міститься віддзеркалюючий шар 5. Отвори у світловоді закриті газопроникною мембраною 10. Другий торець світловоду сполучений з розгалужувачем 6, відповідні гілки якого сполучені з джерелом випромінювання 7 та фотоприймачем 8. Джерело випромінювання та фотоприймач сполучені з блоком живлення та реєстрації 9. Корпус датчика вкритий захисним чохлом 2.

Живлення з блоку живлення та реєстрації надходить до джерела випромінювання, та викликає генерацію випромінювання. Випромінювання, крізь розгалужувач надходить до світловода.

Після контакту датчика 3 середовищем, що містить вуглекислий газ, останній, крізь газопроникну мембрану надходить до внутрішніх отворів світловоду. Під впливом вуглекислого газу змінюються оптичні властивості шару індію-олова. При зміні оптичних властивостей шару індію-олова змінюються умови повного внутрішнього відбивання світла у світловоді. Збільшується частина світла, яка випромінюється поза межі світловоду. Частина світла, що залишилася, відбивається від віддзеркалюючого шару та повертається крізь світловод та відповідну гілку розгалужувача до фотоприймача [6 - 11]. У фотоприймачі створюється електричний сигнал, пропорційний інтенсивності випромінювання, що надійшло від світловоду. Далі електричний сигнал надходить до блоку живлення та реєстрації.

Сигнал, зафіксований у такій спосіб, пропорційний величині концентрації вуглекислого газу у газовій суміші, яка підлягає контролю.

Для компенсації впливу температури навколишнього середовища на елементи пристрою застосовується термокомпенсаційна біметалева оболонка, яка пропорційно температурі, змінює вигин світловода та зменшує заздалегідь внесені втрати випромінювання у світловоді. 
У статичному режимі (калібрування) у блоці живлення та реєстрації фіксуються відповідні данні та поправки, що враховують температуру навколишнього середовища та втрати в усіх елементах вимірювальної системи.

У динамічному режимі (вимірювання), вуглекислий газ взаємодіє 3 шаром індію-олова. В наслідок взаємодії відбувається зміна показника заломлення шару. Зміни, що відбуваються, викликають порушення умов повного відбивання світла у світловоді та ініціюють тунелювання частки випромінювання поза межі світловоду.

Частина світла, що залишилася, відбивається від віддзеркалюючого шару та повертається крізь світловод та відповідну гілку розгалужувача до фотоприймача. У фотоприймачі створюється електричний сигнал, пропорційний інтенсивності випромінювання, що надійшло від світловоду. Далі електричний сигнал надходить до блоку живлення та реєстрації.

Сигнал, що буде зафіксований у такій спосіб, буде пропорційний величині концентрації вуглекислого газу у газовій суміші, яка підлягає контролю.

Для компенсації впливу температури навколишнього середовища на елементи пристрою застосовується термокомпенсаційна біметалева оболонка, яка пропорційно температурі, змінює вигин світловода та зменшує заздалегідь внесені втрати випромінювання у світловоді.

Таким чином, відбувається повний цикл вимірювання.

\section{Висновки}

Технічний ефект досягається завдяки тому, що комбінація оптичних елементів забезпечує:

- відсутність впливу неконтрольованих експлуатаційних та кліматологічних факторів на оптичний канал;

- захищеність чутливих елементів пристрою;

- постійність властивостей оптичного каналу в умовах впливу неконтрольованих експлуатаційних факторів;

- постійне вимірювання у реальному масштабі часу;

- підвищену чутливість та точність приладу.

Використання датчика, що пропонується, дозволить адекватно и достовірно оцінювати параметри газового середовища, що створюється у наслідок згоряння вуглеводневих палив.

\section{Список використаних джерел}

[1]. Ирха, В. И. Процессы, происходящие в полупроводниках при взаимодействии с газовой средой // Наукові праці ОНАЗ ім. О.С. Попова. - 2012. - № 2. - С. 49-54.

[2].Ирха, В. И., Марколенко, П. Ю., Назаренко, А. А., Слободянюк, И.А. Акусто - и оптоэлектронные газочувствительные датчики // Наукові праці ОНАЗ ім. О.С. Попова. - 2015. - № 1. - С. 12-19.

[3].Ирха, В. И., Слободянюк, И. А. Волоконно-оптические сенсоры как анализаторы различных газов // Наукові праці ОНАЗ ім. О.С. Попова, 2017. - № 1. - С. 61-67.

[4].А. с. СССР № 1618123 МКИ G 01 N 27/02. Оптоэлектронный датчик /В.И. Ирха, И.М. Викулин, В.М. Баранов, Ю.Н. Максименко. - № 4492323; заявл. 29.08.1988; опубл. 01.09.1990. Бюл. № 3.

[5].Бусурин, В. И., Носов, Ю.Р. Волоконно-оптические датчики: физические основы, вопросы расчета и применения. - М.: Энергоатомиздат, 1990. - 256 с.

[6].Снайдер, А., Лав, Д. Теория оптических волноводов. - М.: Радио и связь, 1987. - 656 с.

[7].Сандлер, А. К. Оптимізація конструктивних параметрів волоконного акселерометру // Slovak international scientific journal. - 2020. - № 42. - VOL.1. - P. 25-31.

[8].Сандлер, А. К. Метод підвищення ефективності діагностування технічного стану суднових газотурбінних установок на основі волоконно-оптичних технологій: дис. ... канд. техн. наук: 05.22.20. - К., 2021. - 158 с.

[9].Сандлер, А. К. Чувствительный элемент волоконно-оптического акселерометра на основе сапфирового стекла // IX міжнародна науково-методична конференція "Суднова електроінженерія, електроніка і автоматика", 05-06 листопада 2019 р.: матеріали конференції. - Одеса: НУ "ОМА". - 2019. - С. 27-33.

[10]. Сандлер, А. К. Моделирование акселерометра маятникового типа // Вісник Черкаського державного технологічного університету. Серія: Технічні науки. - 2019. - №1. - Черкаси: ЧДТУ. - С. 75-81.

[11]. Сандлер, А. К., Логишев, И. В., Сандлер, А. А. Инвариантный волоконный акселерометр // Енергетика судна: експлуатація та ремонт: матеріали науково-технічної конференції. - Одеса: ОНМА. - 2011. - С. $277-279$.

\section{References}

[1].Irkha, V. I. (2012). Protsessy, proiskhodyashchiye v poluprovodnikakh pri vzaimodeystvii s gazovoy sredoy. [Processes occurring in semiconductors during interaction with a gas medium] // Naukoví pratsi ONAZ im. O.S. Popov. - No. 2. - P. 49 - 54. [in Ukraine].

[2].Irkha, V. I., Markolenko, P. Yu., Nazarenko, A. A., Slobodyanyuk, I.A. (2015). Akusto - i optoelektronnyye gazochuvstvitel'nyye datchiki. [Acousto - and optoelectronic gas sensitive sensors] // Naukovi pratsi ONAZ im. O.S. Popov. - No. 1. - P. 12 - 19. [in Ukraine].

[3].Irkha, V. I., Slobodyanyuk, I. A. (2017). Volokonno-opticheskiye sensory kak analizatory razlichnykh gazov. [Fiberoptic sensors as analyzers of various gases] // Naukovi pratsi ONAZ im. O.S. Popov. - No. 1. - P. 61 - 67.

[4].A. p. USSR No. 1618123 MKI G 01 N 27/02. Optoelectronic sensor / V.I. Irkha, I. M. Vikulin, V. M. Baranov, Yu. N. Maksimenko. - No. 4492323; app. 08/29/1988; publ. 09/01/1990. Bul. No. 3. 
[5].Busurin, V. I, Nosov, Yu. R. (1990). Volokonno-opticheskiye datchiki: fizi-cheskiye osnovy, voprosy rascheta i primeneniya. [Fiber-optic sensors: physical foundations, issues of calculation and application]. -Moscow: Energoatomizdat, - 256 p. [in Russian].

[6].Snyder A., Love D. (1987). Teoriya opticheskikh volnovodov. [Theory of optical waveguides]. - Moscow: Radio i svyaz'. [in Russian].

[7].Sandler, A. K. (2020). Optymizatsiya konstruktyvnykh parametriv volokonnoho akselerometru. [Optimization of design parameters of the fiber accelerometer]. Bratislava: Slovak international scientific journal. - № 42. VOL.1. - P. 25-31. [in Slovak].

[8].Sandler, A. K. (2021). Metod pidvyshchennya efektyvnosti diahnostuvannya tekhnichnoho stanu sudnovykh hazoturbinnykh ustanovok na osnovi volokonno-optychnykh tekhnolohiy [Method of improving the efficiency of diagnosis of the technical condition of ship's gas turbines plants based on fiber-optical technologists]. Kyiv [in Ukraine].

[9].Sandler, A.K. (2019). Chuvstvitel'nyy element volokonno-opticheskogo akselerometra na osnove sapfirovogo stekla. [Sensitive element of a fiber-optic accelerometer based on sapphire glass]. Odessa: IX international scientificmethodical conference "Ship`s electrical engineering, electronics and automation". [in Ukraine].

[10]. Sandler, A. K. (2019). Modelirovaniye akselerometra mayatnikovogo tipa. [Modeling of a pendulum-type accelerometer]. Cherkasy: Bulletin of the Cherkasy State Technological University. -No. 1. - P. 75 - 81. [in Ukraine].

[11]. Sandler, A. K, Logishev, I. V., Sandler, A. A. (2011). Ynvaryantnyy volokonnyy akselerometr. [Invariant fiber-optic accelerometer] // Ship energy: operation and repair: materials of scientific and technical conference. - Odessa: ONMA. P. 277-279. [in Ukraine].

Отримана в редакції 30.06.2021. Прийнята до друку 23.08.2021. Received 30 June 2021. Approved 23 August 2021. Available in Internet 31 September 2021.

\title{
IMPLICATIONS OF UNIVERSITY-BUSINESS COOPERATION \\ FOR HIGHER EDUCATION IN A TIME OF CYBERNETICS: EMERGING TRENDS AND DILEMMAS
}

\author{
Tarasevich I.G. ${ }^{1}$, Tarasevich A. ${ }^{2}$ \\ ${ }^{1}$ National Metallurgical Academy of Ukraine, Dnipro, Ukraine \\ ${ }^{2}$ The University of Western Ontario, London, Ontario, Canada \\ ORCID: ${ }^{1}$ 0000-0002-3249-619X, ${ }^{1}$ 0000-0003-0798-0569 \\ E-mail: ${ }^{1}$ tig-app@ukr.net, ${ }^{2}$ atarasev@uwo.ca
}

Copyright (C) 2021 by author and the journal “Automation of technological and business - processes”.

This work is licensed under the Creative Commons Attribution International License (CC BY).

http://creativecommons.org/licanses/by/4.0

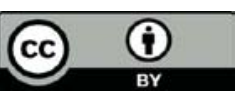

DOI:

"You're either the one that creates the automation or you're getting automated”.

-Tom Preston-Werner, an American billionaire, software developer and entrepreneur

Abstract. Universities and business collaborate for their own ends that do not necessarily match. While the industry is always profit-driven and practice-oriented with primarily short-term goals in mind, the university focuses on strategic planning, theory development, and long-term goals. University-business collaboration (UBC) has diverse modes or activities 